\title{
STRATEGI PENGEMBANGAN AGROINDUSTRI GULA AREN DI DESA TONDEI 1
}

\author{
Novita Wongkar \\ Joachim N. K. Dumais \\ Theodora M. Katiandagho
}

\begin{abstract}
The purpose of this research is to identify the right development strategy in Tondei Village 1, Sub-district of West Motoling, South Minahasa Regency. The research was conducted in September until November 2017, using primary and secondary data with 10 respondents. Data primary collection through interviews using questionnaires. Secondary data collected from the office of Tondei 1 Village. Research data in the analysis using SWOT analysis. The result of the research shows that the result of internal strategic factor analysis shows that the total score of internal analysis result is 3.16 indicating that it is in a "moderate" position in harnessing the strength to face the weakness faced in the development of sugar palm agroindustry in Tondei Village 1. Result of external strategic factor analysis through opportunity and threatened to get a total score of its external analysis is 3.26 which indicates that the development of sugar palm agro-industry is in a strong external position in exploiting the opportunity to overcome the threats faced. *jnkd*
\end{abstract}

Keywords: SWOT analysis, development strategy, sugar palm agroindustry, South Minahasa Regency

\begin{abstract}
ABSTRAK
Tujuan dari penelitian yaitu untuk mengidentifikasi strategi pengembangan yang tepat di Desa Tondei 1. Penelitian dilaksanakan pada bulan September 2017 sampai November 2017, menggunakan data primer dan data sekunder dengan responden sebanyak 10 orang. Pengumpulan data primer melalui wawancara dengan menggunakan daftar pertanyaan. Data sekunder dikumpulkan dari Kantor Desa Tondei 1. Data penelitian primer di analisis menggunakan analisis SWOT. Hasil penelitian menunjukan hasil analisis faktor strategis internal menunjukkan bahwa skor total hasil analisis internal adalah 3.16 yang menandakan berada pada posisi "sedang" dalam memanfaatkan kekuatan untuk menghadapi kelemahan yang dihadapi dalam pengembangan agroindustri gula aren di Desa Tondei 1. Hasil analisis faktor strategis eksternal melalui peluang dan ancaman mendapat skor total analisis eksternalnya adalah 3.26 yang menandakan bahwa pengembangan agroindustri gula aren berada pada posisi ekternal yang "kuat" dalam memanfaatkan peluang untuk mengatasi ancaman yang dihadapi.
\end{abstract}

Kata kunci: analisis SWOT, strategi pengembangan, agroindustri gula aren, Kabupaten Minahasa Selatan 


\section{PENDAHULUAN}

\section{Latar Belakang}

Sektor pertanian masih memegang peranan penting di sebagian besar wilayah Sulawesi Utara, termasuk juga Kabupaten Minahasa Selatan terlebih khusus Kecamatan Motoling Barat. Di Kecamatan Motoling Barat yang menjadi mata pencaharian pokok sebagian besar masyarakat adalah pohon aren, terutama pemanfaatan niranya. Nira aren di olah menjadi gula aren dan "cap tikus". Namun, karena belum adanya strategi pengembangan atas agroekosistem setempat maka hal tersebut dilihat dari kegiatan budi daya, industry pengolahan sampai dengan pemasaran dan pemanfaatannya. Dengan hal itu, peluang yang ada menjadi belum maksimal dimanfaatkan (Evalia, 2015). Pertanian harus disertai dengan pengembangan industri hulu maupun industri hilir agar dapat mendayagunakan keunggulan kompetitif dengan sistem pertanian yang terintegrasi dengan agribisnis dan agroindustri, yang berpijak pada efesiensi, produktivitas, kualitas serta nilai tambah, tanggap terhadap perkembangan ilmu pengetahuan dan teknologi serta penerapan manajemen modern untuk mewujudkan pelaku pertanian yang professional dan beretos kerja industri serta mewujudkan pertanian sebagai wahana untuk menciptakan kesejahteraan dan kemakmuran bagi masyarakat. Agroindustri merupakan salah satu subsistem agribisnis yang strategis yaitu suatu bentuk keterpaduan antara sektor industri dan pertanian. Argroindustri diharapkan sebagai langkah awal pembangunan sektor industri terutama Negara yang didominasi sektor pertanian.

Agroindustri juga menciptakan kondisi yang mendukung industri maju dengan pertanian tangguh, juga memberikan efek ganda melalui penciptaan lapangan kerja, perbaikan distribusi pendapatan, nilai tambah serta pembangunan pertanian yang berbasis agribisnis. Agroindustri pengolahan hasil dari tanaman aren merupakan salah satu agroindustri potensial untuk dikembangkan.
Pengembangan agroindustri gula aren banyak menghadapi kendala yang harus disikapi karena adanya faktor-faktor yang menghambat usaha agroindustri ini, oleh karena itu diperlukan rumusan strategi dalam pengembangannya. Strategi pengembangan agroindustri gula aren harus disesuaikan dengan karakteristik dan permasalahan agroindustri yang bersangkutan. Strategi pengembangan akan berpengaruh dalam menjaga daya saing dan eksistensi usaha sehingga mampu memberikan kontribusi bagi perekonomian keluarga (Saputra, 2012). Gula aren adalah pemanis yang dibuat dari nira yang berasal dari tandan bunga jantan pohon enau atau pohon aren. Gula aren biasa juga diasosiasikan dengan segalah jenis gula yang dibuat dari nira, yaitu cairan yang dikeluarkan dari bunga pohon dari keluarga palma. Beberapa manfaat gula aren diantaranya :

1. Baik untuk penderita diabetes

2. Membuat intensitas istirahat anda lebih baik

3. Cocok dimasukan kedalam makanan untuk diet

4. Pencegah anemia

5. Mengandung antioksida

6. Meningkatkan daya tahan tubuh (Maemonah, 2015)

Desa Tondei terletak di suatu lembah yang diapit oleh dua gunung Lolombulan dan Sinonsayang dengan ketinggian kurang lebih $400 \mathrm{~m}$ dpl. Oleh karena letak yang demikian, maka pada waktu tertentu di saat musim kemarau suhu udara mencapai 26 derajat celcius dan dimusim hujan suhunya menurun sampai 20 derajat celcius. Luas pemukiman desa ini kurang lebih $\mathrm{km} 2$ sedang luas wilayahnya kurang lebih $10 \mathrm{~km} 2$. Secara umum jumlah penduduk didesa Tondei terdapat 2.283 jiwa dengan jumlah keluarga 556 KK. Jumlah penduduk desa Tondei satu laki-laki 637 orang, perempuan 506 orang, dan kepala keluarga 325 KK. Kecamatan Motoling Barat merupakan sentra produksi gula aren di Kabupaten Minahasa Selatan. Di Kecamatan Motoling Barat terdapat tiga desa yang merupakan sentra produksi gula aren yaitu 
Desa Lalumpe, Desa Toyopon dan Desa Tondei. Pohon nira memegang peranan sangat penting karena merupakan tumbuhan/tanaman yang serbaguna, dimana batang bisa digunakan sebagai papan dan gagang cangkul, empelurnya dibuat sebagai makanan sebagai bahan makanan bihun, daun yang digunakan sebagai bahan atap rumah rakyat, ijuk yang dibuat sapu ijuk, buah yang dibuat sebagai kolang-kaling dan bunga yang merupakan nira aren (Anonim, 2008).

Di Desa Tondei nira aren menghasilkan dua produk yaitu gula aren dan captikus. Industri gula aren merupakan usaha yang turun memurun, sehingga dalam pengelolaan masih mengikuti apa yang biasa dilakukan oleh masyarakat pada umumnya proses pembuatan gula aren sebagian besar masih menggunakan peralatan sederhana melalui proses pemasakan nira sampai menjadi gula aren. Terdapat 25 orang pembuat gula aren, yang rutin membuat gula aren sebanyak 15 orang, sedangkan sisanya sebagai usaha sampingan terutama ketika harga gula aren naik. Berat gula aren yang dihasilkan rata-rata 2 kilogram per butir. Kelompok tani ini terbentuk sejak 2014. Kelompok ini sudah bekerja sama dengan kelompok tani Masarang Kota Tomohon. Namun karena keterbatasan modal dan kurang kesadaran serta kekompakan dalam kelompok sehingga masih lemah dalam bermitra. Oleh karena itu, strategi pengembangan agroindustri gula aren yang ditempuh harus disesuaikan dengan karakteristik dan permasalahan agroindustri yang bersangkutan. Strategi pengembangan akan berpengaruh dalam menjaga daya saing atau eksistensi usaha dan mengatasi masalahmasalah yang ada pada usaha agroindustri gula aren.

\section{Rumusan Masalah}

Industri gula aren merupakan usaha yang turun temurun, sehingga dalam pengelolaan masih mengikuti apa yang biasa dilakukan oleh masyarakat pada umumnya. Usaha mengikuti peran industri gula aren agar dapat menjadi mata pencaharian pokok, maka diperlukan strategi yang dapat membantu pengrajin untuk mengembangkan usahanya. Adapun rumusan masalah dalam penelitian ini adalah Strategi apakah yang paling sesuai untuk pengembangan usaha ini?

\section{Tujuan Penelitian}

Tujuan dari penelitian ini adalah untuk menentukan strategi yang tepat dalam pengembangan industri gula aren.

\section{Manfaat Penelitian}

Manfaat dari penelitian ini adalah mampu memberikan gambaran kepada pembaca dan penulis serta mengetahui dengan mendorong masyarakat agar dapat memakai strategi pengembangan agroindustri gula aren di dalam mensejahterakan masyarakat di Desa Tondei 1.

\section{METODOLOGI PENELITIAN}

Tempat Penelitian dan Waktu Penelitian

Penelitian ini akan di lakukan di Desa Tondei 1, Kecamatan Motoling Barat, Kabupaten Minahasa Selatan dengan waktu penelitian selama tiga bulan yaitu bulan September sampai November 2017 di mulai dari persiapan, pengumpulan data, pengolahan data hingga pembuatan laporan sampai penyusunan laporan penelitian.

\section{Metode Pengumpulan Data} ini adalah:

Data yang di gunakan dalam penelitian

1. Data primer

Data primer adalah data yang di ambil langsung dari lokasi melalui pengamatan langsung, wawancara dengan pihak pemerintah, tokoh masyarakat, dan pengisian kuesioer. Pengisian kuesioner untuk tujuan analisis strategi pengembangan agroindustri gula aren di Desa Tondei 1. Responden yang di pilih 10 orang untuk diwawancara dengan bantuan daftar pertanyaan (yang telah disediakan sebelumnya) sebagai berikut :

a. Pemerintah (1 orang), yaitu Ibu Hukum Tua Tondei 1.

b. Tokoh Masyarakat ( 2 orang)

c. Pengrajin Gula Aren ( 7 orang) 
2. Data Sekunder

Data sekunder adalah data yang di peroleh melalui instansi terkait dengan penelitian ini, baik tabulasi maupun deskriptif. Adapun data yang di maksud adalah : jumlah penduduk Tondei Satu.

\section{Metode Pengumpulan Data}

Metode pengumpulan data yang digunakan dalam penelitian ini adalah :

1. Metode Wawancara

Metode ini dilakukan dengan cara melakukan wawancara dan diskusi langsung kepada pemerintah setempat, tokoh masyarakat, dan pengrajin itu sendiri.

2. Metode Observasi

Merupakan survei langsung ke lapangan melalui kegiatan pengamatan, penelitian, dan pengambilan data atau informasi terhadap aspek-aspek yang berkaitan langsung maupun tidak langsung terhadap pengembangan agroindustri.

\section{Metode Pengambilan Sampel}

Pengambilan sampel sebanyak 10 orang yang diambil secara acak sederhana (Simple Random Sampling).

\section{Konsep Pengukuran Variabel}

Adapun variabel yang di teliti yaitu Strategi Pengembangan Agroindustri Gula Aren di Desa Tondei 1 Kecamatan Motoling Barat Kabupaten Minahasa Selatan yaitu :

1. Mengidentifikasi indikator-indikator

Kekuatan (Strengths) yang terdapat di Desa Tondei 1

2. Mengidentifikasi indikator-indikator

Kelemahan (Weakness) yang terdapat di Desa Tondei 1.

3. Mengidentifikasi indikator-indicator

Peluang (Opportunities) yang terdapat di Desa Tondei 1.

4. Mengidentifikasi indikator-indikator Ancaman (Threats) yang terdapat di Desa Tondei 1.
Ada 2 hal yang harus di lihat dalam analisis SWOT yaitu bobot dan rating.

\section{Metode Analisis Data}

Metode analisis yang digunakan dalam mengidentifikasi strategi pengembanan agroindustri gula aren di desa tondei satu adalah dengan menggunakan Analisis SWOT. Menurut Rangkuti (2015), Analisis SWOT yaitu membandingkan antara faktor eksternal peluang (opportunities) dan ancaman (threats) dengan faktor internal kekuatan (strengths), dan kelemahan (weaknesses). Dalam melakukan pertimbangan profesional pada analisis faktor strategis internal dan eksternal memiliki pembatas. Pembobotan pada lingkungan internal tingkat kepentingannya di dasarkan pada besarnya pengaruh faktor strategis terhadap posisi strategisnya, sedangkan pada lingkungan eksternal didasarkan pada kemungkinan memberikan dampak terhadap faktor strategisnya (Rangkuti, 2015). Jumlah bobot pada masing - masing lingkungan internal dan eksternal harus berjumlah $=1$ (satu) :

Skor total internal $\rightarrow$ total bobot kekuatan + total bobot kelemahan $=1$

Skor total ekstemal $\rightarrow$ total bobot peluang + total bobot ancaman $=1$

Sedangkan nilai bobot menurut Freddy Rangkuti (2015) berdasarkan ketentuan sebagai berikut :

"Skala 1.0 (sangat penting) sampai dengan 0,0 (tidak penting)"

Besarnya rata - rata nilai bobot tergantung pada jumlah faktor strategisnya (5-10 faktor strategis) yang dipakai. Nilai rating berdasarkan besarnya pengaruh faktor strategis terhadap kondisi dirinya (Rangkuti, 2015) dengan ketentuan sebagai berikut:

1. Skala mulai dari 4 (sangat kuat), 3 (kuat), 2 (kurang kuat) sampai dengan 1 (tidak kuat / lemah).

2. Variabel yang bersifat positif (variabel kekuatan dan peluang) diberi nilai dari 1 sampai dengan 4 dengan membandingkan dengan rata - rata pesaing utama / kondisi wilayah didaerah lain. Sedangkan variable yang bersifat negative kebalikannya, jika kelemahan dan ancaman besar sekali (dibanding dengan rata-rata pesaing sejenis) 
nilainya adalah 1 , sedangkan ancaman kecil di bawah rata - rata pesaingnya nilainya adalah 4.

Matrik SWOT adalah matrik yang mengintraksikan faktor strategis internal dan eksternal. Matrik ini dapat menggambarkan secara jelas bagaimana peluang dan ancaman (eksternal) yang dihadapi dapat disesuaikan dengan kekuatan dan kelemahan (internal) yang dimiliki. Hasil dari interaksi faktor strategis internal dengan eksternal menghasilkan alternative-alternative strategi. Matrik SWOT menggambarkan berbagai altemative strategi yang dilakukan didasarkan hasil analisis SWOT. Strategi SO adalah strategi yang menggunakan seluruh kekuatan yang kita miliki untuk merebut peluang. Sedang strategi WO adalah strategi yang meminimalkan kelemahan untuk merebut peluang. Strategi ST adalah strategi yang di susun dengan menggunakan seluruh kekuatan yang di miliki untuk mengatasi ancaman yang akan terjadi. Strategi WT adalah strategi yang di susun dengan meminimalkan kelemahan untuk menghindari ancaman.

a. Analisis faktor- faktor strategis internal dan ekstemal (IFAS - EFAS)

Analisis faktor strategi internal dan ekstemal adalah pengolahan faktor-faktor strategis pada lingkungan intemal dan ekstemal dengan memberikan pembobotan dan rating pada setiap faktor srtategis.

\section{Tabel 1. Matriks IFAS dan EFAS}

\begin{tabular}{|c|c|c|c|}
\hline Faktor Strategi & Bobot & Rating & Skor \\
\hline $\begin{array}{l}\text { Internal: } \\
\text { - Strength }(\mathrm{S}) \\
\text { - Weakness }(\mathrm{W})\end{array}$ & $\begin{array}{l}\text { S1 }(0,0-1,0) \\
\text { W1 }(0,0-1,0)\end{array}$ & $\begin{array}{l}\text { S2 (1-4) } \\
\text { W2 (1-4) }\end{array}$ & $\begin{array}{l}\mathrm{S} 1 \times \mathrm{S} 2=\mathrm{S} 3 \\
\mathrm{~W} 1 \times \mathrm{W} 2=\mathrm{W} 3\end{array}$ \\
\hline Total & 1,0 & & \\
\hline $\begin{array}{l}\text { Eksternal: } \\
\text { - Opportunity } \\
\text { (O) } \\
\text { - Treaths }(\mathrm{T})\end{array}$ & $\begin{array}{l}\text { O1 }(0,0-1,0) \\
\text { T1 }(0,0-1,0)\end{array}$ & $\begin{array}{l}\text { O2 (1-4) } \\
\text { T2 (1-4) }\end{array}$ & $\begin{array}{l}\mathrm{O} 1 \times \mathrm{O} 2=\mathrm{O} 3 \\
\mathrm{~T} 1 \times \mathrm{T} 2=\mathrm{T} 3\end{array}$ \\
\hline Total & 1,0 & & \\
\hline
\end{tabular}

Menganalisis Iingkungan internal (IFAS) untuk mengetahui berbagai kemungkinan kekuatan dan kelemahan. Menganalisis lingkungan eksternal (EFAS) untuk mengetahui berbagai kemungkinan peluang dan ancaman.

1) Kolom 1 : Disusun faktor-faktor yang menjadi kekuatan, kelemahan, peluang dan ancaman perusahaan.

2) Kolom 2 : Memberikan bobot masingmasing faktor dengan skala mulai dari 1,0 (sangat penting) sampai 0,0 (tidak penting). Pemberian bobot setiap variabel menunjukan pengaruh masing-masing variabel terhadap faktor strategi perusahaan. Menurut Kinnear (1991) dalam Mappigau dan Esso (2011), bobot setiap variabel diperoleh dengan menentukan nilai setiap variabel terhadap jumlah nilai keseluruhan variabel dengan menggunakan rumus :

$\alpha \mathrm{i}=\frac{x i}{\sum_{i=1}^{n} x i}$

Dimana :

$\alpha i=$ bobot variabel ke-i

$\mathrm{xi}=$ nilai variabel ke-i

$\mathrm{i}=1,2,3$,

$\mathrm{n}=$ jumlah variabel

3) Kolom 3 : Hitung rating (dalam kolom 3) untuk masing-masing faktor denagan memberikan skala mulai dari 4 (outstanding) sampai dengan 1 (poor) berdasarkan pengaruh faktor tersebut terhadap kondisi perusahaan yang bersangkutan. Pemberian nilai rating untuk faktor peluang bersifat positif (peluang yang semakin besar diberi rating +4 , tetapi jika peluangnya kecil, diberi rating +1 ). Pemberian nilai rating ancaman adalah kebalikannya. Misalnya, jika nilai ancamannya sangat besar, ratingnya adalah 1. Sebaliknya, jika nilai ancamannya sedikit ratingnya 4 . Variabel yang bersifat positif (semua variabel yang masuk kategori kekuatan) diberi nilai +1 sampai dengan +4 (sangat baik) dengan membandingkan rata industri atau dengan pesaing utama. Sedangkan variabel yang bersifat negatif kebalikanya

4) Pada kolom 4 : Mengalikan bobot dan rating untuk memperoleh skor pembobotan. Setelah mengetahui skor pembobotan, jumlahkan skor pembobotan (kolom 4) untuk memperoleh total skor pembobotan 
bagi perusahaan yang bersangkutan. Nilai total ini menunjukan bagaimana perusahaan tertentu beraksi terhadap faktor-faktor strategis. Berdasarkan strategi yang digunakan dalam matriks SWOT maka model

b. Pemetaan posisi agroindustri gula aren

Pemetaan posisi agroindustri bertujuan untuk mengetahui posisi agroindustri gula aren dalam perkembangannya saat ini. Pemetaan didasarkan pada analogi sifat yang dimiliki dari faktor-faktor strategis. Kekuatan memiliki sifat positif, kelemahan bersifat negatif, begitu juga dengan peluang bersifat positif dan ancaman bersifat negativ. Diagram posisi perkembangan agroindustri memberikan gambaran keadaan perkembangan agroindustri gula aren berdasarkan kuadran-kuadran yang dihasilkan garis Vektor SW dan garis Vektor OT, setiap kuadran memiliki rumusan strategi sebagai strategi utamanya. Seperti lelah dijelaskan sebelumnya garis Vektor pada diagram posisi perkembangan agroindustri di dasarkan pada logika faktor strategi internal membentuk garis horisontal dan faktor strategi eksternal membentuk garis vertikal.

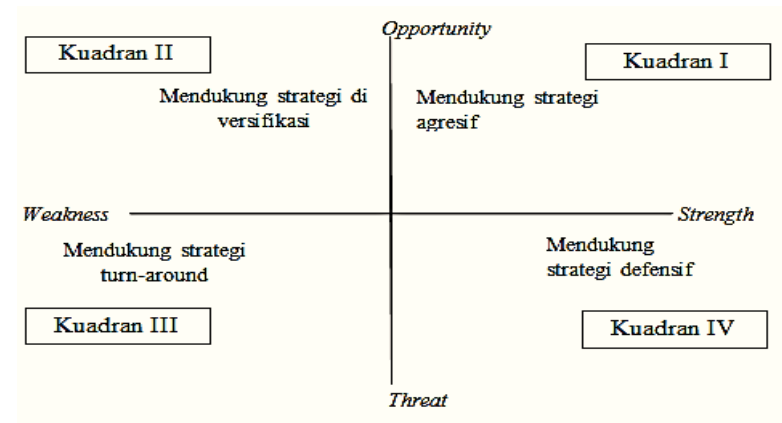

Gambar 1. Model Posisi Perkembangan Agroindustri Sumber: Rangkuti, 2015

Rumusan setiap kuadran yang secara khusus untuk agroindustri dan beberapa pengertian yang melalui proses adopsi, adaptasi dari penggunaan analisis SWOT untuk perusahaan, sehingga diadaptasi sutu rumusan sebagai berikut :

1) Kuadran 1 : ini merupakan situasi yang sangat menguntungkan memiliki peluang dan kekuatan sehingga dapat memanfaatkan peluang yang ada. Strategi yang harus di terapkan dalam kondisi ini adalah mendukung kebijakan pertumbuhan yang agresif (growth oriented strategy).
2) Kuadran $2:$ meskipun menghadapi berbagai ancaman, perusahaan masih memiliki kekuatan dari segi internal. Strategi yang harus diterapkan adalah menggunakan kekuatan untuk memanfaatkan peluang jangka panjang dengan strategi diversifikasi (produk/pasar).

3) Kuadran 3 : perusahaan meghadapi peluang pasar yang sangat besar, tetapi di lain pihak, ia menghadapi beberapa kendala/kelemahan internal. Kondisi bisnis pada kuadran 3 ini mirip dengan Quention Mark pada BCG Matrrix. Fokus perusahaan ini adalah meminimalkan masalah-masalah internal perusahaan sehingga dapat merebut peluang pasar yang lebih baik.

4) Kuadran 4 : ini merupakan situasi yang sangat tidak menguntungkan, perusahaan tersebut menghadapi berbagai ancaman dan kelemahan internal.

Berdasarkan strategi yang digunakan matriks SWOT maka model matriks yang akan digunakan berdasarkan Tabel 2 berikut ini :

\begin{tabular}{|c|c|c|}
\hline $\begin{array}{l}\text { INTERNAL (IFAS) } \\
\text { EKSTERNAL } \\
\text { (EFAS) }\end{array}$ & Kekuatan (S) & Kelemahan (W) \\
\hline Peluang (O) & $\begin{array}{l}\text { Strategi SO } \\
\text { (Strategi yang } \\
\text { menggunakan } \\
\text { kekuatan dan } \\
\text { memanfaatkan } \\
\text { peluang) }\end{array}$ & $\begin{array}{l}\text { Strategi WO } \\
\text { (Strategi yang } \\
\text { meminimalkan } \\
\text { kelemahan dan } \\
\text { memanfaatkan } \\
\text { peluang) }\end{array}$ \\
\hline Ancaman (T) & $\begin{array}{l}\text { Strategi ST } \\
\text { (Strategi yang } \\
\text { menggunakan } \\
\text { kekuatan dan } \\
\text { mengatasi } \\
\text { ancaman) }\end{array}$ & $\begin{array}{l}\text { Strategi WT } \\
\text { (Strategi yang } \\
\text { meminimalkan } \\
\text { kelemahan dan } \\
\text { menghindari } \\
\text { ancaman) }\end{array}$ \\
\hline
\end{tabular}

Alternative strategi merupakan hasil matrik analisis SWOT yang menghasilkan berupa strategi SO, WO, ST, dan WT. Alternative strategi yang dihasilkan minimal 4 (empat) strategi sebagai hasil dari analisis matrîk SWOT.

1. Strategi SO, strategi ini dibuat berdasarkan jalan pikiran memanfaatkan seluruh kekuatan untuk merebut dan memanfaatkan peluang.

2. Strategi ST, strategi dalam menggunakan kekuatan yang dimiliki untuk mengatasi ancaman.

3. Strategi WO, diterapkan berdasarkan pemanfaatan peluang yang ada dengan cara meminimalkan kelemahan yang ada. 
4. Strategi WT, didasarkan pada kegiatan usaha meminimalkan kelemahan yang ada serta menghindari ancaman.

\section{HASIL DAN PEMBAHASAN}

\section{Gambaran Umum Lokasi Penelitian}

Desa Tondei terletak di suatu lembah yang diapit oleh dua gunung Lolombulan dan Sinonsayang dengan ketinggian kurang lebih 400 $\mathrm{m}$ dpl. Oleh karena letak yang demikian, maka pada waktu tertentu di saat musim kemarau suhu udara mencapai 26 derajat celcius dan dimusim hujan suhunya menurun sampai 20 derajat celcius. Luas pemukiman desa ini kurang lebih km2 sedang luas wilayahnya kurang lebih $10 \mathrm{~km} 2$. Secara umum jumlah penduduk didesa Tondei terdapat 2.283 jiwa dengan jumlah keluarga $556 \mathrm{KK}$. Jumlah penduduk desa Tondei satu laki-laki 637 orang, perempuan 506 orang, dan kepala keluarga 325 KK. Batas wilayah Desa Tondei, yaitu :

a. Sebelah Utara berbatasan dengan wilayah Desa Ongkau dan Tiniawangko

b. Sebelah Selatan berbatasan dengan wilayah Desa Raan baru

c. Sebelah Timur berbatasan dengan Gunung Lolombulan

d. Sebelah Barat berbatasan dengan Gunung Sinonsayang

Kedudukan desa Tondei, sebagian agak landai dan sebagian agak datar. Bagian yang agak landai disebut "kampung gunung", dan bagian yang datar disebut "kampung liba". Kira-kira 1 $\mathrm{km}$ sebelah utara desa ini pada jalan menuju Ongkau dan Tiniawangko terdapat satu kampung yang baru dengan nama Lumopa dan kadangkadang disebut juga dengan Lopana.

Pembagian penduduk di Desa Tondei, dapat disajikan sebagai berikut: Jumlah penduduk di Desa Tondei 1 :

$\begin{array}{ll}\text { Laki-laki } & : 637 \text { Orang } \\ \text { Perempuan } & : 506 \text { Orang } \\ \text { Kepala keluarga } & : 325 \mathrm{KK}\end{array}$

\section{Kondisi Geografis}

\section{Aspek Fisik Dasar}

Desa Tondei terletak di lembah yang diapit oleh dua gunung, yaitu gunung Lolombulan di sebelah timur dan gunung Sinonsayang disebelah barat, kira-kira $9 \mathrm{~km}$ dari pantai. Oleh karena letaknya demikian, maka pada waktu tertentu silih berganti berhembus angin pegunungan dan angin laut. Sebagian besar wilahnya adalah lahan perkebunan yang didominasi oleh tanaman cengkih dan kelapa. Kedua jenis komoditi ini sanfat baik pertumbuhannya karena iklimnya sangat cocok untuk tanaman perkebunan secara umum seiring dengan laju pertumbuhan penduduk maka terjadi alih fungsi lahan dari lahan hutan menjadi lahan perkebunan sehingga sekarang ini luas lahan hutan makin berkurang.

\section{Aspek Demografi}

\section{Keadaan Alam}

Keadaan tanahnya sangat subur dan sangat baik bagi tanaman perkebunan dan pertanian. Luas pemukiman desa ini kurang lebih $1 \mathrm{~km} 2$ sedang luas wilayahnya kurang lebih $10 \mathrm{~km} 2$. Pada sebelah utara berbatasan dengan Wilayah Desa Ongkau dan Tiniawangko, sebelah timur dengan gunung Lolombulan, sebelah selatan dengan wilayah desa Raanan Baru dan pada sebelah barat dengan gunung Sinonsayang. Tondei umumnya, terletak kurang lebih $400 \mathrm{~m}$ dpl pada sebelah timur berdiri megah gunung Lolombulan dan perbukitan Kantil, sebelah barat gunung Sinonsayang dengan perbukitan Paembongan, pakuntungan dan pondos. Di sebelah utara mengalir anak sungai Tondei lebih ke utara timur laut mengalir sungai Wawa, kaluntai kecil, aser, kaluntai wangko dan kokitong. Di sebelah timur mengalir sungai Raanan, di sebelah selatan mengalir sungai suka, komanga'ang, neang, sedangkan di sebelah barat mengalir sungai raringis.

\section{Lingkungan Hidup}

Jalan yang ada di Desa Tondei sudah dapat dilewati kendaraan bermotor dan kendaraan mobil untuk mengeluarkan hasil pertanian seperti kopra, gula aren dan sebagainya ke Motoling dan Ongkaw. Desa Tondei juga di hubungkan dengan desa Pantai Ongkaw dengan sebuah jalan yang panjangnya lebih dari $9 \mathrm{~km}$ dari desa Ongkaw jalan ini sudah diaspal sampai ke desa Tondei. Desa Tondei merupakan desa penghasil kopra 
terbesar di kecamatan Motoling dan merupakan sentra produksi gula aren di kecamatan Motoling barat. Sehingga dibutuhkan jalan yang baik untuk dapat menyalurkan penghasilannya ke pasaran.

\section{Pertanian}

Perkembangan di bidang pertanian, perikanan dan peternakan agak lamban. Kebanyakan petani masih merupakan petani alamiah karena suburnya tanah pertanian maka masih jarang orang menggunakan pupuk. Kebanyakan masih mempraktekkan cara-cara tradisional dalam mengelolah tanahnya.

\section{Mata Pencaharian atau Perekonomian}

Menurut data yang di dapat mengenai jenis pekerjaan sebagian besar penduduk yang bermukim di desa Tondei sebagian besar adalah petani dan sebagian kecil yang bekerja sebagai PNS, POLRI, Pensiunan, Wiraswasta, Swasta, dll. Mata pencaharian Desa Tondei 1 adalah bertani untuk tanaman musiman, petani bercocok tanam jagung, sedangkan untuk tanaman tahunan masyarakat desa Tondei bercocok tanam kelapa, cengkih, dan panili. Di samping itu banyak juga petani mengelolah gula merah atau gulah aren dan captikus karena di wilayah Desa Tondei banyak tanaman seho atau pohon enau.

\section{Industri}

Tondei merupakan suatu desa penghasil kopra nomor satu di kecamatan Motoling, penghasil cengkih yang menanjak pada tiap-tiap musim pemetikan dan merupakan sentra produksi gula aren di kecamatan Motoling Barat. Maka besar kemungkinan pada waktu mendatang suatu perusahaan minyak, perusahaan gula aren dan cengkih akan terdapat di desa ini.

\section{Gambaran Umum Industri Gula Aren di Desa Tondei 1}

Di Desa Tondei merupakan sentra produksi gula aren. Industri gula aren merupakan usaha yang turun memurun, sehingga dalam pengelolaan masih mengikuti apa yang biasa dilakukan oleh masyarakat pada umumnya. Jumlah pohon aren yang ada di Desa Tondei 1 yaitu 528 pohon aren atau seho di mana setiap pengrajin mempunyai pohon aren dengan bervariasi ada yang 22 satu pengrajin dan ada juga yang mempunyai dengan rata-rata 20 pohon aren 25 pengrajin maka jumlah semua pohon aren adalah 528 pohon aren dan jika kehabisan nira maka pengrajin akan mengontrak pohon aren yang lain dengan harga 1 juta 6 pohon aren. Proses pembuatan gula aren memakan waktu sehari mulai dari pukul 06.00 pagi sampai pukul 16.00 sore ada pula yang sampai pukul 17.00 sore. Sebagian besar pengrajin masih menggunakan peralatan sederhana seperti Wajan, penggayung yang terbuat dari bambu, penampung air nira yang terbuat dari bambu, tempurung sebagai tempat cetakan gula aren 1 kali produksi dengan 40 liter air nira dengan proses pemasakan nira sampai menjadi gula aren dengan hasil produksi 5 butir dengan berat 2 kilogram dan 8 liter air nira bisa menghasilkan $1 \mathrm{~kg}$ gula aren. Terdapat 25 orang pembuat gula aren di Desa Tondei 1, yang rutin membuat gula aren sebanyak 15 orang, sedangkan sisanya sebagai usaha sampingan terutama ketika harga gula aren naik. Berat gula aren yang dihasilkan rata-rata 2 kilogram per butir dengan harga 1 kilogram di jual Rp 10 ribu. Jumlah pedagang yang ada di Desa Tondei 1 yaitu 7 orang. Sistem pemasarannya yaitu pengrajin jual kepada pedagang pengumpul dan pedagang pengumpul menjual atau memasarkan gula aren ke manado, bitung, pasar-pasar, perusahan kecap maupun sebagian ke rumah-rumah makan yang berbahan baku gula aren dan yang membutuhkan gula aren.

\section{Karakteristik Responden}

\section{Umur Responden}

Umur responden dapat mempengaruhi kemampuan seseorang untuk bekerja secara fisik serta dapat menentukan persepsi seseorang. Umur juga dapat mempengaruhi produktifitas kerja dan peranan dalam proses pengambilan keputusan dalam berbagai pekerjaan yang di lakukan. Umur produktifitas 15 hingga 56 tahun, jumlah responden di sajikan pada Tabel 3.

Berdasarkan Tabel 3 dapat di lihat jumlah responden menurut umur petani yang terbanyak pada umur 30-40 tahun dan sebagiannya yaitu umur 40-50 tahun. 


\begin{tabular}{lll} 
Tabel & $\begin{array}{l}\text { 3. Jumlah Responden menurut } \\
\text { Tondei 1 Kecamatan Motoling Barat }\end{array}$ \\
\hline No & $\begin{array}{l}\text { Umur } \\
\text { (Tahun) }\end{array}$ & $\begin{array}{l}\text { Jumlah Responden } \\
\text { (Orang) }\end{array}$ \\
\hline 1. & $30-40$ & 8 \\
2. & $40-50$ & 1 \\
3. & $>50$ & 1 \\
Jumlah & 10 \\
\hline
\end{tabular}

\section{Tingkat Pendidikan Responden}

Pendidikan sangat berperan penting dalam menciptakan perubahan dalam masyarakat. Pendidikan juga dapat memberikan pemahaman akan baik dan buruk, garis pemisah antara sesuatu yang boleh dan yang tidak boleh di lakukan. Pendidikan di sajikan sebagai salah satu faktor yang menentukanb produktifitas kerja, sikap serta kemampuan seseorang dalam berpikir dan bertindak. Berdasarkan hasil penelitian, tingkat pendidikan responden bervariasi mulai dari Sekolah Dasar (SD), Sekolah Menengah Pertama (SMP), Sekolah Menengah Atas (SMA), dapat di lihat pada Tabel 4.

Tabel 4. Jumlah Responden menurut Tingkat Pendidikan di Desa Tondei Kecamatan Motoling Barat

\begin{tabular}{lll}
\hline No & $\begin{array}{l}\text { Tingkat } \\
\text { Pendidikan }\end{array}$ & $\begin{array}{l}\text { Jumlah Responden } \\
\text { (Orang) }\end{array}$ \\
\hline 1. & SD & 6 \\
2. & SMP & 4 \\
3. & SMA & - \\
Jumlah & 10 \\
\hline
\end{tabular}

Berdasarkan Tabel 4. dapat di lihat jumlah responden menurut tingkat pendidikan petani untuk gula aren terbanyak pada tingkat pendidikan SD yaitu 6 orang dan sabagiannya di tingkat pendidikan SMP yaitu 4 orang.

\section{Analisis Strategi Pengembangan Agroindustri Gula Aren di Desa Tondei 1}

Dalam menganalisis strategi pengembangan agroindustri gula aren di Desa Tondei 1 dapat menggunakan analisis SWOT. Maka dari itu menggunakan Faktor Internal dan Faktor Eksternal, yaitu :

Faktor Internal :

1) Kekuatan (Strengths)

a. Jumlah pohon aren

b. SDM (pengrajin)

c. Peralatan/sarana produksi

d. Akses ke Tondei

e. Pedagang pengumpul

f. Modal kerja
2) Kelemahan (Weakness)

a. Jaringan komunikasi

b. Kerjasama antar pengrajin

c. Regenerasi pengrajin

Faktor Eksternal

1) Peluang (Opportunities)

a. Meningkatnya industri makanan berbahan baku gula aren

b. Dukungan teknis dari pemerintah

2) Ancaman (Threats)

a. Berkembangnya Industri gula aren di sekitarnya

b. Kurangnya minat masyarakat terhadap produk

\section{Analisis Faktor Internal (IFAS)}

Analisis lingkungan internal yang dilakukan yaitu terhadap faktor-faktor strategi internal yang terdiri dari kekuatan dan kelemahan dalam pengembangan agroindustri gula aren di Desa Tondei 1.Dapat dilihat pada Tabel 5 berikut ini:

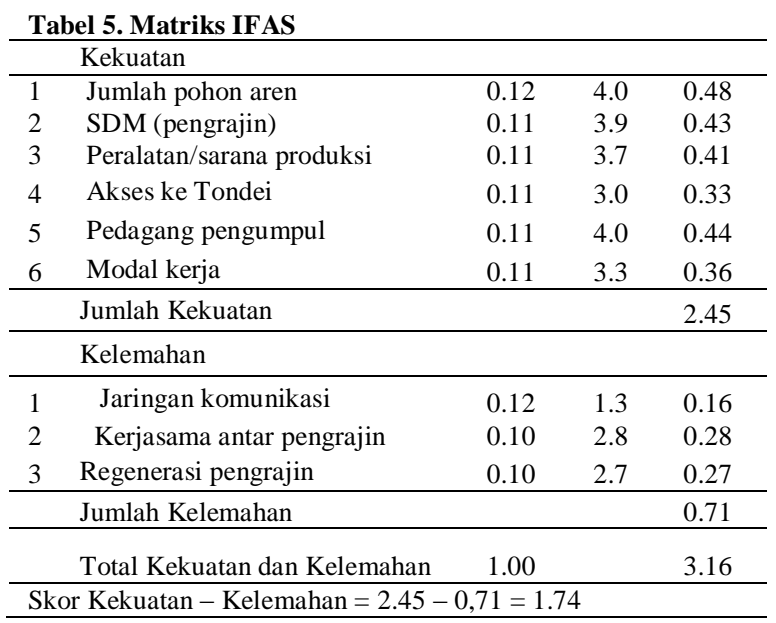

\section{Analisis Faktor Eksternal (EFAS)}

Analisis kondisi eksternal di lakukan terhadap faktor-faktor strategis yang terdiri atas peluang dan ancaman dalam pengembangan agroindustri gula aren di Desa Tondei 1. Adapun faktor-faktor strategi eksternal yang dimaksud dapat di lihat pada Tabel 6.

Hasil analisis faktor strategis eksternal melalui peluang dan ancamn mendapat skor total analisis eksternalnya adalah 3.26 yang menandakan bahwa pengembagan 
agroindustri gula aren berada pada posisi ekternal yang "kuat" dalam memanfaatkan peluang untuk mengatasi ancaman yang dihadapi. Adapun peluang terbesar yang di miliki dalam pengembangan agroindustri gula aren adalah dukungan teknis dari pemerintah, khususnya di Desa Tondei 1 dengan skor eksternal 1.08, dan didukung dengan adanya peluang meningkatnya industri makanan berbahan baku gula aren dengan skor eksternal 1.05. Kemudian yang menjadi ancaman utamanya adalah berkembangnya industri gula aren di sekitarnya dengan skor eksternal 0.67, di ikuti dengan dengan kurangnya minat masyarakat terhadap produk dengan skor eksternal 0.46 .

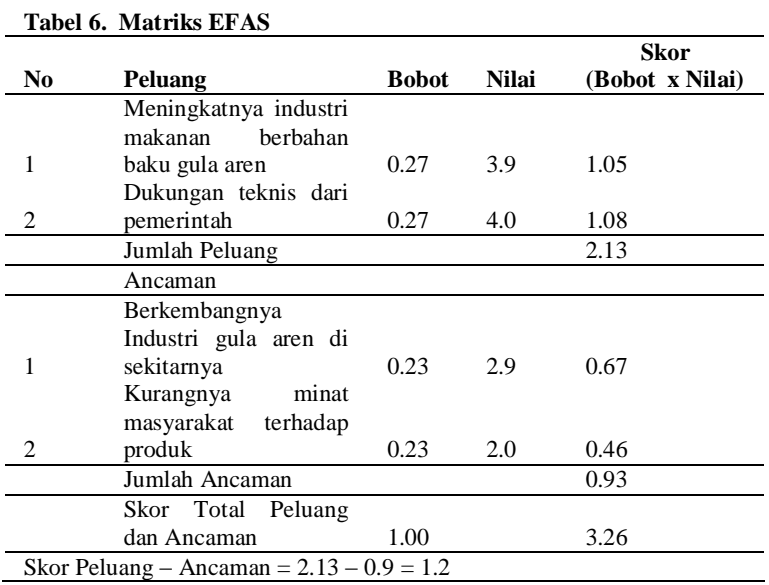

\section{Pemetaan Posisi Agroindustri}

Menentukan posisi agrowisata dengan cara memadukan kekuatan, kelemahan, peluang, dan ancaman sehingga dapat ditentukan titik koordinat dan dipetakan pada matriks posisi.

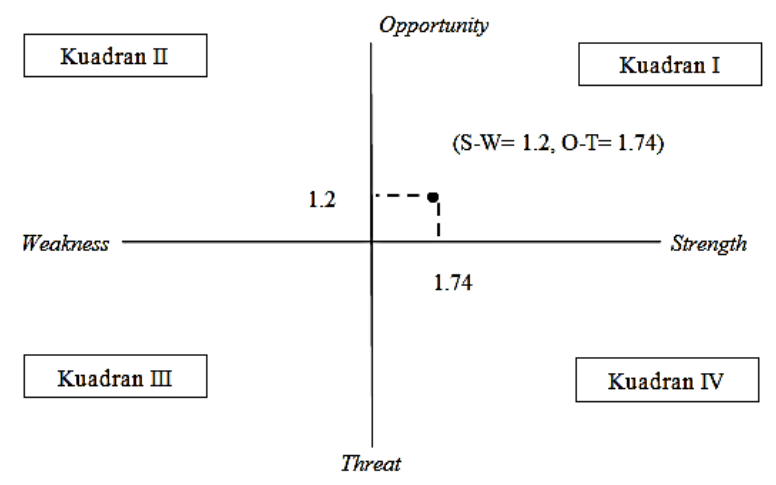

Gambar 2. Matriks Posisi Pengembangan agroindustri gula aren di Desa Tondei 1
Dari gambar 2 diatas, dapat dilihat bahwa posisi relatif agroindustri gula aren di Desa Tondei $(1.2,1.74)$ pada kuadran I yang menunjukan bahwa agroindustri gula aren di Desa Tondei 1 memiliki kekuatan dan peluang sehingga dapat memanfaatkan peluang yang ada dengan menggunakan kekuatan yang dimiliki. Strategi pengembangan yang sesuai dengan posisi agroindustri gula aren di Desa Tondei 1 adalah strategi S-O.

\section{Pemetaan Posisi Agroindustri}

Alternatif strategi merupakan hasil mariks analisis SWOT yang menghasilkan beberapa strategi S-O, W-O, S-T, dan W-T. Alternatif strategi yang dihasilkan dari matriks SWOT adalah sebagai berikut:

Tabel 7. Matrriks Analisis SWOT

\begin{tabular}{|c|c|c|}
\hline Eksternal & Kekuatan (S) & Kelemahan (W) \\
\hline Peluang (O) & $\begin{array}{ll}\text { Strategi SO } \\
\text { a. } & \text { Memanfaatkan } \\
& \text { pohon aren } \\
& \text { yang ada untuk } \\
& \text { menarik } \\
\text { investor } & \text { sehingga } \\
\text { menjadi sentra } \\
\text { produksi yang } \\
\text { semakin } \\
\text { berkembang. } \\
\text { Memanfaatkan } \\
\text { dukungan } \\
\text { pemerintah } \\
\text { untuk } \\
\text { perkembangan } \\
\text { agroindustri } \\
\text { gula aren di } \\
\text { Desa Tondei. }\end{array}$ & \begin{tabular}{ll}
\multicolumn{2}{l}{ Strategi WO } \\
a. & Meningkatka \\
& n kerjasama \\
antar & \\
pengrajin & dalam \\
perkembanga & n \\
& agroindustri \\
& gula aren. \\
beningkatny & \\
a industri \\
makanan \\
berbahan \\
baku gula \\
aren serta \\
memaksimal \\
kan promosi \\
untuk \\
menarik \\
komsumen.
\end{tabular} \\
\hline $\begin{array}{l}\text { Ancaman } \\
\text { (T) }\end{array}$ & 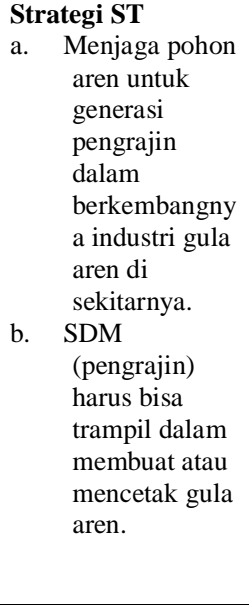 & $\begin{array}{l}\text { Strategi WT } \\
\text { a. } \quad \text { Meningkatkan } \\
\text { jaringan } \\
\text { komunikasi } \\
\text { dalam } \\
\text { menghindari } \\
\text { berkembangn } \\
\text { ya industri } \\
\text { gula aren. } \\
\text { b. } \quad \text { Meningkatkan } \\
\text { kesadaran } \\
\text { dalam } \\
\text { menjaga } \\
\text { kerjasama } \\
\text { antar } \\
\text { pengrajin } \\
\text { untu } \\
\text { regeneras } \\
\text { pengrajin. }\end{array}$ \\
\hline
\end{tabular}


Dari beberapa uraian di atas, menunjukkan bahwa agroindustri gula aren di Desa Tondei 1 berada pada posisi yang kuat dan berpeluang. Rekomendasi strategi yang diberikan dapat memanfaatkan peluang yang ada dengan menggunakan kekuatan yang dimiliki. Maka rekomendasi strategi yang diberikan adalah Strategi S-O.

\section{KESIMPULAN DAN SARAN}

\section{Kesimpulan}

Berdasarkan hasil penelitian dan pembahasan, maka dapat di simpulkan bahwa agroindustri gula aren di Desa Tondei 1 memiliki kekuatan dan peluang sehingga dapat memanfaatkan peluang yang ada dengan menggunakan kekuatan yang di miliki. Strategi pengembangan yang sesuai dengan posisi agroindustri gula aren di Desa Tondei 1 adalah strategi S-O. Pengembangan agroindustri berada pada posisi "sedang", melalui beberapa strategi yang dapat di implementasikan yaitu : Strategi SO Memanfaatkan pohon aren yang ada untuk menarik investor sehingga menjadi sentra produksi yang semakin berkembang. Dan Memanfaatkan dukungan pemerintah untuk perkembangan agroindustri gula aren di Desa Tondei. Strategi WO Meningkatkan kerjasama antar pengrajin dalam perkembangan agroindustri gula aren. Dan Meningkatnya industri makanan berbahan baku gula aren serta memaksimalkan promosi untuk menarik komsumen. Strategi ST Menjaga pohon aren untuk generasi pengrajin dalam berkembangnya industri gula aren di sekitarnya. Dan SDM (pengrajin) harus bisa trampil dalam membuat atau mencetak gula aren. Strategi WT Meningkatkan jaringan komunikasi dalam menghindari berkembangnya industri gula aren. Dan Meningkatkan kesadaran dalam menjaga kerjasama antar pengrajin untuk regeneras pengrajin.

\section{Saran}

Adapun hal-hal yang dapat disarankan dalam rangka pengembangan agroindustri gula aren adalah berusaha untuk mempertahankan kekuatan untuk menghadapi kelemahan yang dihadapi dan memanfaatkan peluang yang ada dalam pengembangan agroindustri gula aren di Desa Tondei 1 . Diharapkan masyarakat dan pemerintah harus lebih memperhatikan dalam hal ini jaringan komuniksi agar tidak berkembangnya industri gula aren di sekitarnya.

\section{DAFTAR PUSTAKA}

Anonim. 2008. Tanaman Enau. Diakses pada tanggal 5 Mei 2011. 2008 Produk Olahan Aren.

Saragih, Bungaran. 2010. Agribisnis Paradigma Baru Pembangunan Ekonomi Berbasis Pertanian. PT Penerbit IPB Press Kampus IPB Taman Kencana Bogor.

David, Fred R. 2012. Manajemen Strategi. Salemba Empat J1. Raya Lenteng Agung No. 101 Jagakarsa, Jakarta

Edi Saputra, Laily Fitriana, Edwar Bahar. 2012. Strategi Pengembangan Usaha Gula Aren di Desa Rambah Tengah Barat Kecamatan Rambah Kabupaten Rokan Hulu. Fakultas Pertanian Universitas Pasir Pengaraian.

Gumbira dan Intan. 2001. Manajemen Agribisnis. Ghalia Indonesia. Jakarta.

Lempang, Mody. 2012. Pohon Aren dan Manfaat Produksinya. Balai Penelitian Kehutanan Makassar, Jl. Perintis Kemerdekaan Km.16 Makassar Oktober

Nur Afni Evalia. 2015. Strategi Pengembangan Agroindustri Gula Semut Aren. Journal Program Studi Agribisnis, Fakultas Pertanian, Universitas Andalas Kampus Unand Limau Manis, Padang 2516

Pontoh, Julius. 2013. Penentuan Kandungan Sukrosa pada Gula Aren dengan Metode Enzimatik 
Rangkuti, F. 2015. Analisis SWOT : Teknik Membedah Kasus Bisnis Cara Perhitungan Bobot, Rating, dan OCAI. Jakarta: Penebit PT.Gramedia Pustaka Utama

Rangkuti, Freddy. 2009 . Analisis SWOT.

Rangkuti, Freddy. 1997. Analisis SWOT Teknik Membedahkan Kasus Bisnis. PT Gramedia Pusta-ka Utama, anggota IKAPI, Jakarta, Agustus

Rangkuti, Freddy. 2015. Personal Analisis SWOT. PT Gramedia Pustaka Utama anggota IKAPI, Jakarta.

Maemonah, Siti. 2015. "Strategi Pengembangan Industri Kecil Gula Aren di Kecamatan Limbangan Kabupaten Kendal". Skripsi Jurusan Ekonomi Pembangunan Fakultas Ekonomi Universitas Negeri Semarang.
Soekartawi. 2000. Agroindustri dalam prospektif social Ekonomi. PT Raja Grafindo Persada

Sujarweni, V. Wiratna. 2014. Metodologi penelitian. Yogyakarta: Pustaka Baru.

Widiwati, Sri. 2001. Pemanfaatan Hasil Samping Penggilingan Padi dalam Menunjang Sistem Agroindustri di Pedesaan. Balai Penelitian Bioteknologi Tanaman Pangan, Bogor

Wuri Marsigit 2005. Penggunaan Bahan Tambahan pada Nira dan Mutu Gula Aren yang di Hasilkan di beberapa Sentra Produksi di Bengkulu

Yusjda Yusmichad dan Ilami Nyak. 2004. "Tinjauan Kebijakan Pengembangan Agribisnis Sapi Potong”. Pusat Penelitian dan Pengembangan Sosial Ekonomi Pertanian Jl. A. Yani, No. 70 Bogor 